\title{
Calibration Method for a Structured Light Rangefinder Using a Reference Plane
}

\author{
Koichiro Yamauchi Non-member (Keio University, yamauchi@hvrl.ics.keio.ac.jp) \\ Hideo Saito Member (Keio University, saito@hvrl.ics.keio.ac.jp) \\ Yukio Sato Non-member (Keio University, satoy@ics.keio.ac.jp)
}

Keywords: rangefinder, three-dimensional measurement, geometric model, calibration

It has been challenging to capture a highly accurate 3D shape of a target object using a projector-camera pair. Attempts have been made using the pinhole model to represent the camera and projector geometry and a cubic object to estimate calibration parameters. The projector cannot emit light stripes through the same pinhole when scanning by a rotatable mirror. In addition, it is preferable to estimate the parameters using a two-dimensional object. In this paper, the problem of calibrating a structured light rangefinder is addressed.

A structured light rangefinder is composed of a camera and a projector. The rangefinder allows $3 \mathrm{D}$ reconstruction when the camera observes a light stripe on a target object illuminated by the projector. Fig. 1 is the geometric model of a structured light rangefinder. Both the camera and the projector are represented in the camera coordinate system. The camera model is based on the pinhole model of perspective projection. The projector model is based on the equation of a plane model. Even if light stripes are emitted in different directions, the proposed geometric model is applicable to various structured light rangefinders.

Our approach to calibrating a structured light rangefinder incorporates two separate stages: camera calibration and projector calibration. Two parameters set are estimated by observing a reference plane from unknown viewpoints as shown in Fig. 2.

In the camera calibration stage, camera parameters are obtained by Zhang's method. The camera calibration matrix is estimated from perspective projections and homographies between image plane and reference plane. Then, the rotation matrix, translation vector, and radial distortion coefficients

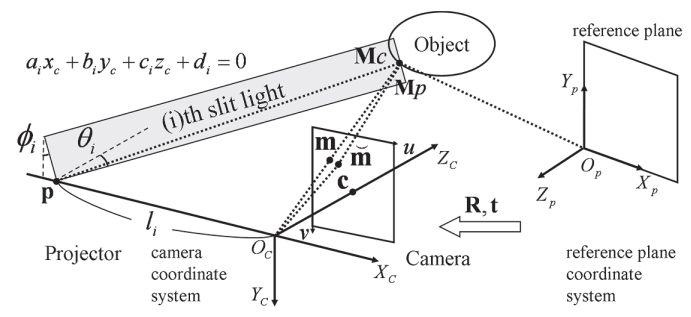

Fig. 1. Geometric model are computed. The camera parameters are optimized with a nonlinear refinement based on the maximum likelihood criterion.

In the projector calibration stage, we estimate projector parameters, i.e. the equation of a plane for light stripe, using the $4 \times 3$ image-to-camera transformation matrix which can be directly computed by the camera parameters without recalculation. The light stripe is illuminated on the reference planes as shown in Fig. 3, so that a segment of the line is projected onto the image plane. The matrix allows the light stripe image-to-camera transformation. Therefore, the coefficients of the equation of a plane can be estimated by the least squares method with at least three image coordinates.

In the experiments, it has proven that our approach to calibrate the rangefinder, defined that the projector model is using the equations of a plane, achieves high accuracy measurements. The calibration method using a reference plane obtains similar results to the traditional methods using a slide stage.

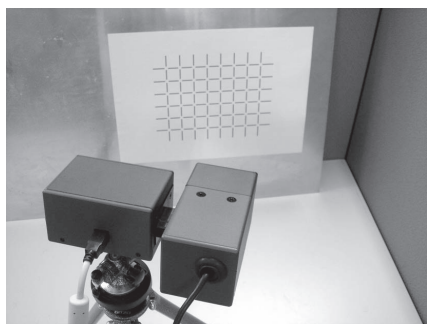

Fig. 2. Calibration scene

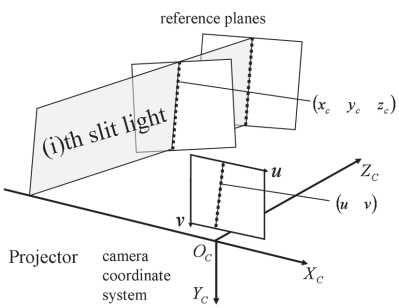

Fig. 3. Projector calibration 


\title{
基準平面を用いたスリット光投影式レンジファインダの校正
}

\author{
非会員 山内 航一郎* 正 員 斎藤 英雄* \\ 非会員 佐藤 幸男*
}

Calibration Method for a Structured Light Rangefinder Using a Reference Plane

Koichiro Yamauchi*, Non-member, Hideo Saito*, Member, Yukio Sato*, Non-member

It is challenging to capture a highly accurate 3D shape of a target object using a projector-camera pair. Attempts have been made using the pinhole model to represent the camera and projector geometry and a cubic object to estimate calibration parameters. The projector cannot emit light stripes through the same pinhole when scanning by a rotatable mirror. In addition, it is preferable to estimate the parameters using a two-dimensional object. In this paper, the problem of calibrating a structured light rangefinder is addressed. Unlike previous work, the projection of a light stripe from the projector is expressed by the equation of a plane. The coefficients of each light stripe's equation are estimated by observing a reference plane from unknown viewpoints. Experimental results demonstrate a high degree of accuracy compared to conventional methods.

キーワード : レンジファインダ, 三次元計測, 幾何モデル, 校正

Keywords: rangefinder, three-dimensional measurement, geometric model, calibration

\section{1. はじめに}

スリット光投影式のレンジファインダはカメラとプロジェ クタから構成されており, 物体の三次元形状を取得するも のである。三次元形状はプロジェクタから対象物体へスリッ ト光を照射し，その反射光をカメラから観測すれば，対象 物の表面上の測定点として得られる。

これまでに開発あるいは製品化された能動型レンジファ インダはいくつかあり, スリット光を投影する方法が広く 利用されている。Konica Minolta 社の VIVID 910 は，ス リット光走査に基づく光切断法 ${ }^{(1)}$ によって計測を行ってい る。また，スペースビジョン社の Cartesiaは，スリット光 をパターン光投影から生成する空間コード化法 ${ }^{(2)}$ を用いて いる。これらの測定器は，いずれも確実かつ高精度な三次 元形状を得ることを目的としており，スリット光を用いる ことによってそれを実現している。

この能動型距離計測においては, カメラとプロジェクタ の幾何学的関係をあらかじめ取得しておくことが必要であ る。このために, 従来は, カメラとプロジェクタを, ピン ホールモデルとして, $3 \times 4$ カメラ行列, $2 \times 4$ 投影行列に

\footnotetext{
* 慶應義塾大学

干 223-8522 神奈川県横浜市港北区日吉 3-14-1

Keio University

Hiyoshi 3-14-1, Kohoku-Ku, Yokohama 223-8522, Japan
}

よって表現し, 両者の変換行列の推定によって校正が行わ れていた ${ }^{(3)}$ 。しかし, ピンホールモデルはカメラのモデル 化には適していても，プロジェクタのスリット光投影機構 の構造は必ずしもピンホールモデルで正確に表現すること ができない。たとえば, プロジェクタがガルバノミラーや ポリゴンミラーで構成されている場合, 走査されるすべて のスリット光がピンホールを通ると仮定することは難しい。 そこで，こうしたプロジェクタの構造をモデルに適用する 方法が提案されている。

植芝ら ${ }^{(4)}$ はプロジェクタの光源および回転ミラーに対す るモデルを提案している。プロジェク夕内部では, 光源から の光が平面状に絞られてミラーに入射し, ミラーに与えら れた回転角に応じた方向へスリット光が反射される。この 反射されたスリット光にミラーの仰角パラメータを加える ことによって，ミラーの回転角度のねじれを表現している。

服部ら (5) はプロジェクタの回転ミラーの角度を基線長に 利用したモデルを提案している。奥行き座標を計算するた めには, カメラのピンホールとプロジェクタの光源との距 離である基線長が必要になる。しかし，ミラーを使ったス リット光走査を行う場合には, 基線長がその回転角によっ て変化してしまう。そのため, ミラーの回転角度を用いる ことによって基線長を表している。

本論文では，従来手法で用いられているようなプロジェ クタの構造に依存して定義される幾何学的パラメータを用 


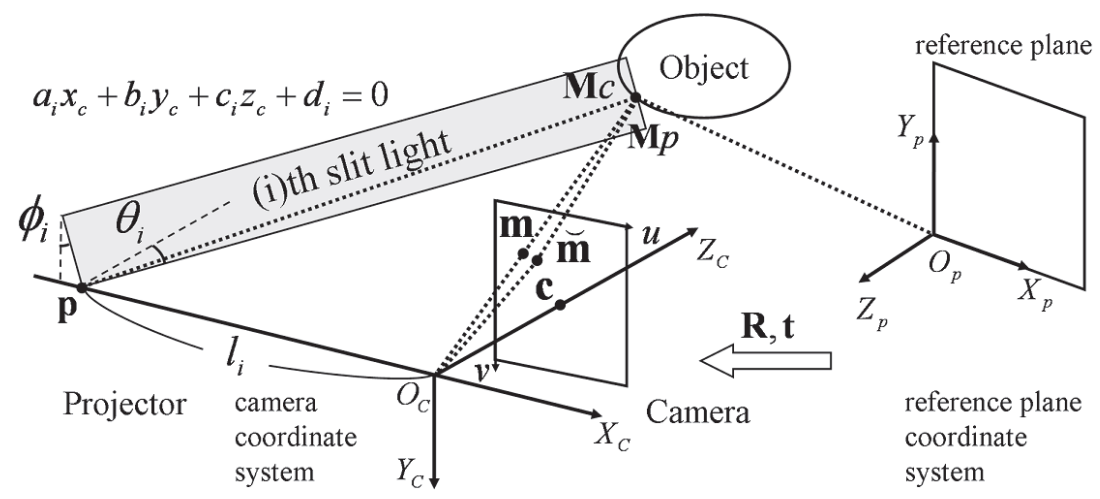

Fig. 1. Geometric model for a structured light rangefinder.

いるのではなく，すべてのスリット光を平面方程式によっ て表現することに基づいた投影モデルを提案する。このモ デルは,スリット光を利用した全てのプロジェクタに利用 可能である。

そして, この平面方程式を推定するための手段として, 基 準平面を用いた簡便な校正手法を提案する。本手法では，校 正点が描かれた基準平面を三視点から観測することによっ てレンジファインダの校正を行う。このように基準平面を 利用するだけで校正が可能になるため，スライドステージ や直方体のような立体的な治具を用いる方法 ${ }^{(6)}$ と比べて作 業は容易になる。

実験では，提案法の有用性を検証するために，スライド テーブルを使って平面方程式を推定する方法と同等の三次 元計測精度が実現できることを示す。

\section{2. 幾何モデル}

スリット光投影式のレンジファインダはカメラとプロジェ クタから構成されており, 物体の三次元形状を取得する。 三次元形状はプロジェクタから対象物体ヘスリット光を投 影し，その反射光をカメラから観測することによって得ら れる。本論文では，カメラの幾何をピンホールモデル，プ ロジェクタから照射されるスリット光を平面方程式で定義 したモデルを用いる。図 1 はレンジファインダの幾何を表 すモデルである。レンジファインダのカメラとプロジェク 夕の位置と姿勢はともにカメラ座標系において記述してお り，校正で用いる基準平面は基準平面座標系において定義 されている。以下，カメラとプロジェクタのモデル，計測 原理について説明する。

〈2·1 カメラモデル ピンホールモデルとは三次元 空間における物体の光がすべて，ある一点 $O_{c}$ を通過する ことを仮定したものである。カメラの光軸と画像面の交点 c を画像中心 $\left[u_{0}, v_{0}\right]$ と呼び, カメラ座標系の $X_{c}$ 軸と $Y_{c}$ 軸をそれぞれ画像面と平行にとり， $Z_{c}$ 軸は光軸に対して平 行と定義している。このとき, 画像面における二次元点の 画像座標 $\mathbf{m}$ は $[u, v]$ と, カメラ座標系 $\left(O_{c}-X_{c}-Y_{c}-Z_{c}\right)$ に おける三次元点のカメラ座標 $\mathbf{M}_{c}$ は $\left[x_{c}, y_{c}, z_{c}\right]$ と表す。

校正に用いる基準平面上に原点 $O_{p}$ と $X_{p}, Y_{p}$ 軸を定め,
$Z_{p}$ 軸は基準平面に対して垂直方向に定義する。基準平面 座標系 $\left(O_{p}-X_{p}-Y_{p}-Z_{p}\right)$ における三次元点の基準平面座標 $\mathbf{M}_{p}$ は $\left[x_{p}, y_{p}, z_{p}\right]$ と記す。

基準平面座標 $\mathbf{M}_{p}$ と画像座標 $\mathbf{m}$ の関係は

$$
\begin{aligned}
& \widetilde{\mathbf{m}} \simeq \mathbf{A}\left[\begin{array}{ll}
\mathbf{R} & \mathbf{t}
\end{array}\right] \widetilde{\mathbf{M}}_{p} \ldots \ldots \\
& \text { where } \quad \mathbf{A}=\left[\begin{array}{ccc}
\alpha & \gamma & u_{0} \\
0 & \beta & v_{0} \\
0 & 0 & 1
\end{array}\right]
\end{aligned}
$$

と表される。式中の（）は斉次座標であることを示して いる。 $\mathbf{A}$ はカメラの内部パラメー夕行列, $\mathbf{R}$ は回転行列, $\mathbf{t}$ は並進べクトルを表す。 $\mathbf{A}$ に含まれる各要素 $\alpha, \beta, \gamma$, $u_{0}, v_{0}$ はカメラの内部パラメータ, $\mathbf{R}, \mathbf{t}$ はカメラの外部 パラメータである(7)。

さらに，基準平面座標 $\mathbf{M}_{p}$ とカメラ座標 $\mathbf{M}_{c}$ との関係は 外部パラメータを使って

$$
\begin{aligned}
& \mathbf{M}_{c}=\left[\begin{array}{ll}
\mathbf{R} & \mathbf{t}
\end{array}\right] \widetilde{\mathbf{M}}_{p} \ldots \ldots \ldots \\
& \text { where } \mathbf{R}=\left[\begin{array}{lll}
\mathbf{r}_{1} & \mathbf{r}_{2} & \mathbf{r}_{3}
\end{array}\right]
\end{aligned}
$$

と記述できる。 $\mathbf{r}_{1}, \mathbf{r}_{2}, \mathbf{r}_{3}$ はカメラ座標系から見た基準平 面座標系の $X_{p}, Y_{p}, Z_{p}$ 軸の方向を表す単位べクトルであ る。 $\mathbf{t}$ は基準平面座標系原点 $O_{p}$ を始点, カメラ座標系原点 $O_{c}$ を終点とするべクトルを表す。つまり, カメラパラメー 夕が得られると, 基準平面から画像面への射影変換および カメラ座標系から見た基準平面の位置と姿勢が分かる。

実際のカメラで撮影された画像は，レンズによって歪め られ, 理想的なピンホールカメラとは異なった画像が得ら れる。このようなレンズ収差によって歪められた画像を補正 するためには，レンズの放射歪曲について考慮する必要が ある。レンズ歪みの影響を受けた画像座標 $\breve{\mathbf{m}}$ を $[\breve{u}, \breve{v}]$ と表 す。 $[\breve{u}, \breve{v}]$ と歪みのない理想的な画像座標 $[u, v]$ との関係は

$$
\begin{gathered}
\breve{u}=u+\left(u-u_{0}\right)\left[k_{1}\left(x^{2}+y^{2}\right)+k_{2}\left(x^{2}+y^{2}\right)^{2}\right] \\
\ldots \ldots \ldots \ldots \ldots \ldots \cdots \cdots \\
\breve{v}=v+\left(v-v_{0}\right)\left[k_{1}\left(x^{2}+y^{2}\right)+k_{2}\left(x^{2}+y^{2}\right)^{2}\right]
\end{gathered}
$$


と表される。 $k_{1}, k_{2}$ はカメラのレンズ歪み係数, $[x, y]$ は 正規化画像座標である。この正規化画像座標とは焦点距離 1 と仮定したときの画像座標を意味しており,

$$
\left[\begin{array}{l}
x \\
y \\
1
\end{array}\right]=\mathbf{A}^{-1}\left[\begin{array}{l}
u \\
v \\
1
\end{array}\right]
$$

と表される。つまり， $\mathbf{A} ， k_{1}, k_{2}$ が得られれば，歪みを受 けた $[\breve{u}, \breve{v}]$ から，歪みを受けていない理想的な $[u, v]$ を推 定することができる(8)。

〈2・2〉 プロジェクタモデルプロジェクタから照射 されるすべてのスリット光を平面方程式として表したプロ ジェクタのモデルを提案する。スリット光はカメラ座標系 に掠いて

$$
a_{i} x_{c}+b_{i} y_{c}+c_{i} z_{c}+d_{i}=0
$$

と定義する。添字 $i$ はスリット光の番号, $a_{i}, b_{i}, c_{i}, d_{i}$ は 平面方程式の係数を示す。これらの係数をプロジェクタパ ラメータと呼ぶ。

スリット光と $X_{c}$ 軸との交点を $\mathbf{p}$ として, $O_{c}$ と $\mathbf{p}$ との 距離を基線長 $l_{i}$ とする。また, スリット光と $Z_{c}$ 軸, $Y_{c}$ 軸 とのなす角をそれぞれ投影角 $\theta_{i}$, 倒立角 $\phi_{i}$ と定義する。こ れらの変数は, 平面方程式の係数から

$$
\begin{aligned}
l_{i} & =d_{i} / a_{i} \ldots \ldots \ldots \\
\theta_{i} & =\arctan \left(-c_{i} / a_{i}\right) \\
\phi_{i} & =\arctan \left(-b_{i} / a_{i}\right)
\end{aligned}
$$

と計算できる。このように，明示的にカメラとプロジェク 夕間の基線長，スリット光の投影角と倒立角が得られる。

このモデルでは，スリット光が空間において平面である と見なして，すべてのスリット光に対してそれぞれ平面方 程式を定義している。そのため, スリット光がどのような 方向に照射された場合に打いても，プロジェクタにより投 影されるスリット光の幾何学的構造を表すことができるの である。

$\langle 2 \cdot 3\rangle$ 計測原理 物体の三次元形状はプロジェク夕 から対象物ヘスリット光を投影し，その反射光をカメラか ら観測することにより，その表面上の測定点として得られ る。つまり, 対象物体の表面上の測定点はカメラの視線方 向とスリット光の平面方程式との交点にある。

はじめに, カメラとプロジェクタのモデルを用いれば, 式 (1), 式 (2) および式 (6) から $\left[x_{c} / z_{c}, y_{c} / z_{c}, 1 / z_{c}\right]$ について

$$
\left[\begin{array}{ccc}
\alpha & \gamma & 0 \\
0 & \beta & 0 \\
a_{i} & b_{i} & d_{i}
\end{array}\right]\left[\begin{array}{c}
x_{c} / z_{c} \\
y_{c} / z_{c} \\
1 / z_{c}
\end{array}\right]=\left[\begin{array}{c}
u-u_{0} \\
v-v_{0} \\
-c_{i}
\end{array}\right] \cdots
$$

と表現できる。次に, カメラ座標 $\left[x_{c}, y_{c}, z_{c}\right]$ につて (10) 式を解くと

$$
x_{c}=\frac{\left(u-u_{0}\right)-\frac{\gamma}{\beta}\left(v-v_{0}\right)}{\alpha} z_{c} \ldots \ldots \ldots \ldots
$$

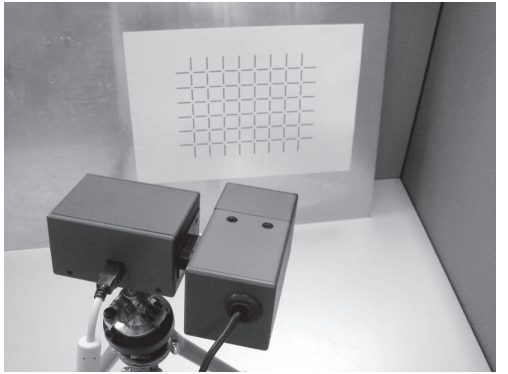

Fig. 2. Calibration scene.

$$
\begin{aligned}
& y_{c}=\frac{v-v_{0}}{\beta} z_{c} \ldots \ldots \ldots \ldots \ldots \ldots \ldots \ldots \\
& z_{c}=\frac{\frac{d_{i}}{a_{i}}}{-\frac{c_{i}}{a_{i}}-\frac{\left(u-u_{0}\right)-\frac{\gamma}{\beta}\left(v-v_{0}\right)}{\alpha}-\frac{b_{i}}{a_{i}} \frac{\left(v-v_{0}\right)}{\beta}} \cdots
\end{aligned}
$$

となる。カメラの視線方向とスリット光の平面方程式から 奥行き值 $z_{c}$ は推定され， $x_{c}, y_{c}$ は先に算定された $z_{c}$ とカ メラに関する相似の関係から求められている。したがって, カメラとプロジェクタのパラメータが既知であれば，対象 物体上の三次元点のカメラ座標を計算することができる。

また, 式 (13) は平面方程式の係数を基線長, 投影角, 倒 立角で置き換えると

$$
z_{c}=\frac{l_{i}}{\tan \theta_{i}-\frac{\left(u-u_{0}\right)-\frac{\gamma}{\beta}\left(v-v_{0}\right)}{\alpha}+\tan \phi_{i} \frac{\left(v-v_{0}\right)}{\beta}}
$$

となる。これは三角形の一辺と侠角による三角測量である ことを意味する。

\section{3. 校正手法}

レンジファインダの三次元計測を可能にするためにはカ メラとプロジェクタのパラメータを求める必要がある。本 論文では, 基準平面を三視点から観測することによってカ メラとプロジェクタのパラメータを推定する校正手法につ いて提案する。図 2 は基準平面を観測するレンジファイン ダである。基準平面には格子模様が描かれており，この模 様の交点を校正点として利用する。すべての校正点には基 準平面座標が与えられる。校正には，基準平面を撮影した 輝度画像，スリット光が照射された基準平面を撮影したス リット光画像が三組必要となる。はじめに, カメラパラメー 夕を推定し，それをもとに，プロジェクタパラメー夕を求 める。

〈3・1〉 カメラパラメータ 基準平面を三視点から観 測することによってカメラの校正を行う Zhang の手法 ${ }^{(9)}$ を利用する。図 3 は基準平面とカメラとの関係を示してい る。カメラパラメー夕は, 基準平面上の校正点の基準平面 座標 $\mathbf{M}_{p}$ と, その画像面への投影像の画像座標 $\mathbf{m}$ を与え ると，それらの間の対応関倸から推定することができる。

カメラの校正に必要な三枚の輝度画像は, レンジファイ ンダを移動させて基準平面を撮影することにより取得する。 


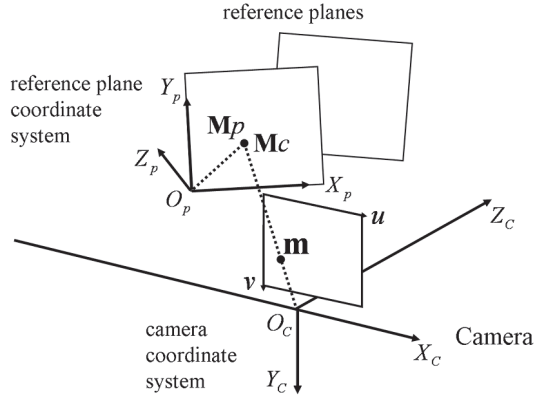

Fig. 3. Camera calibration.

このとき, レンジファインダは基準平面に対して位置と姿 勢が変わるように設置しなければならない。もし，基準平面 に対して同じ姿勢のままで，位置だけを変えた場合には，力 メラパラメータを推定することができないためである ${ }^{(10)}$ 。

〈3·2〉 プロジェクタパラメータカメラパラメータ を利用したスリット光の平面方程式を推定する新たな方法 について提案する。カメラパラメータが得られると, 基準 平面から画像面への射影変換と, カメラから見た基準平面 の位置と姿勢が分かるため, 基準平面上の任意の画像座標 からカメラ座標への変換行列を推定することができる。こ の変換行列を用いると, 基準平面に照射したスリット光と 基準平面との交線上のカメラ座標が計算できるため, これ らの座標に対して平面を当てはめれば，スリット光の平面 方程式を推定することが可能になる。

はじめに，基準平面から画像面への射影変換ならびにカ メラから見た基準平面の位置と姿勢を表す式の導出を行う。 (1) 式は基準平面から画像面への射影変換を表しており，画 像座標 $\mathbf{m}$ と基準平面座標 $\mathbf{M}_{p}$ の関係は, $Z_{p}$ 軸が基準平面 に対して垂直方向に定義されているため, $z_{p}=0$ とするこ とにより,

$$
\widetilde{\mathbf{m}} \simeq \mathbf{A Q}\left[\begin{array}{c}
x_{p} \\
y_{p} \\
1
\end{array}\right]
$$

と表される。 $\mathbf{Q}=\left[\begin{array}{lll}\mathbf{r}_{1} & \mathbf{r}_{2} & \mathbf{t}\end{array}\right]$ はカメラの外部パラメータを 用いた $3 \times 3$ 行列である。次に，(2) 式はカメラから見た基 準平面の位置と姿勢を表しており, 基準平面座標 $\mathbf{M}_{p}$ とカ メラ座標 $\mathbf{M}_{c}$ の関係は, $z_{p}=0$ とすることによって

$$
\mathbf{M}_{c}=\mathbf{Q}\left[\begin{array}{c}
x_{p} \\
y_{p} \\
1
\end{array}\right]
$$

と記述できる。さらに，Q⿻逆行列は

$$
\begin{aligned}
\mathbf{Q}^{-1} & =\left[\begin{array}{lll}
\mathbf{r}_{1} & \mathbf{r}_{2} & \mathbf{t}
\end{array}\right]^{-1} \\
& =\frac{1}{\left(\mathbf{r}_{1} \times \mathbf{r}_{2}\right)^{T} \mathbf{t}}\left[\begin{array}{c}
\left(\mathbf{r}_{2} \times \mathbf{t}\right)^{T} \\
\left(\mathbf{t} \times \mathbf{r}_{1}\right)^{T} \\
\left(\mathbf{r}_{1} \times \mathbf{r}_{2}\right)^{T}
\end{array}\right]
\end{aligned}
$$

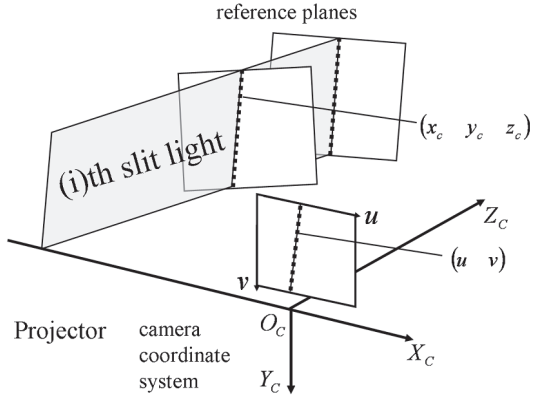

Fig. 4. Projector calibration.

$$
=\frac{1}{\mathbf{r}_{3}^{T} \mathbf{t}}\left[\begin{array}{c}
\left(\mathbf{r}_{2} \times \mathbf{t}\right)^{T} \\
\left(\mathbf{t} \times \mathbf{r}_{1}\right)^{T} \\
\mathbf{r}_{3}^{T}
\end{array}\right]
$$

となる。式中の $(T)$ は行列とべクトルの転置を表す。†

したがって，これら三式を用いれば，画像座標 $\mathbf{m}$ とカメ ラ座標 $\mathbf{M}_{c}$ との関係は,

$$
\begin{aligned}
\widetilde{\mathbf{M}}_{c} & =\left[\begin{array}{c}
\mathbf{M}_{c} \\
1
\end{array}\right]=\left[\begin{array}{c}
\mathbf{Q} \\
\mathbf{k}^{T}
\end{array}\right]\left[\begin{array}{c}
x_{p} \\
y_{p} \\
1
\end{array}\right] \\
& \simeq\left[\begin{array}{c}
\mathbf{Q} \\
\mathbf{k}^{T}
\end{array}\right] \mathbf{Q}^{-1} \mathbf{A}^{-1} \widetilde{\mathbf{m}} \\
& \simeq\left[\begin{array}{c}
\mathbf{I} \\
\left(\mathbf{r}_{3}^{T} \mathbf{t}\right)^{-1} \mathbf{r}_{3}^{T}
\end{array}\right] \mathbf{A}^{-1} \widetilde{\mathbf{m}} \ldots \ldots
\end{aligned}
$$

where $\mathbf{k}=[0,0,1] \quad \mathbf{I}=\operatorname{diag}(1,1,1)$

と関係づけられる。画像座標からカメラ座標への変換行列 はカメラパラメータのみで表されており, カメラの校正が 終われば容易に求めることができる。これにより，基準平 面に照射したスリット光と基準平面との交線上のカメラ座 標を求めることが可能になる。

図 4 はスリット光と基準平面との関係を示している。二 枚の基準平面にはそれぞれスリット光が照射され，画像面 にはそれらの投影像が現れている。(18) 式から, $i$ 番目ス リット光が投影されている画像面の画像座標 $\mathbf{m}$ からカメ ラ座標 $\mathbf{M}_{c}$ が得られる。スリット光の平面方程式は, この 二平面の座標に平面のあてはめを行うことによって推定で きる。

(6) 式において平面方程式は係数 $a_{i}, b_{i}, c_{i}, d_{i}$ で定義さ れているが，これらの係数には定数倍の不定性がある。三 次元空間中における平面は三点で決定されるため, 三点以 上のカメラ座標から平面方程式は求められる。また, 一枚の 基準平面のみにスリット光が投影されている場合には，三 次元空間において平面を決定することができないため，二 枚以上の基準平面にスリット光を照射する必要がある。

\section{4. 実 験}

実験ではスペースビジョン社のスリット光投影式レンジ 


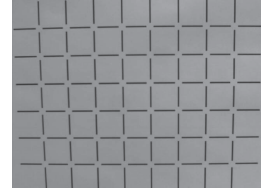

Color image 1

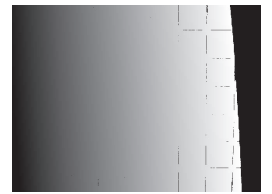

Slit image 1
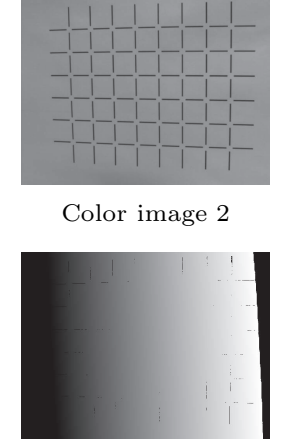

Slit image 2
Color image 2

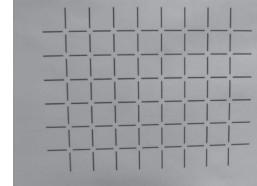

Color image 3

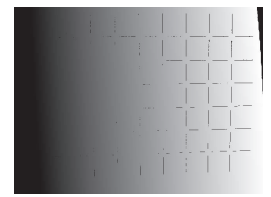

Slit image 3
Fig. 5. Color images and slit light images.

Table 1. Camera parameters.

\begin{tabular}{c|ccc}
\hline & & & \\
$\mathbf{A}$ & {$\left[\begin{array}{ccc}1061.71 & -0.562002 & 350.08 \\
0 & 1064.09 & 286.547 \\
0 & 0 & 1\end{array}\right]$} \\
& {$[3$} & -0.140279 \\
\hline$k_{1}$ & \multicolumn{3}{|c}{-0.0916363} \\
\hline$k_{2}$ & \multicolumn{3}{|c}{} \\
\hline
\end{tabular}

ファインダ Cartesia ${ }^{(11)}$ を用いた。これはカメラ（焦点距 離 $8 \mathrm{~mm}$, 解像度 $640 \times 480$ 画素）とプロジェクタ（スリッ 卜光 254 本）から構成されており，スリット光はポリゴン ミラーによって走査される。以下，このレンジファインダ を使った校正と精度評価の実験結果について述べる。

$\langle\mathbf{4} \cdot \mathbf{1}\rangle$ 校 正 校正には基準平面を三視点から撮 影した三組の輝度画像とスリット光画像を利用した。図 5 は撮影した輝度画像とスリット光画像である。輝度画像の 格子模様の垂直方向と水平方向の線分に対してそれぞれ直 線のあてはめを行い，その二つの直線の交点から校正点の 画像座標を得る。また，スリット光画像の輝度值 1～254 は スリット光の番号に対応している。

表 1 はZhang の手法より得られたカメラの内部パラメー 夕行列とレンズ歪み係数である。また, 図 6 は提案法によっ て推定されたスリット光の平面方程式の基線長 $l_{i}$, 投影角 $\theta_{i}$, 倒立角 $\phi_{i}$ を示している。基線長はスリット光の番号が 大きくなるにしたがって，距離が短くなることが分かる。投 影角はスリット光の番号が増加するごとに大きくなり，倒 立角はほぼ一定值となっている。こうして得られたカメラ とプロジェクタのパラメータを用いることによって三次元 計測が可能となる。

〈4・2〉 精度評価＼cjkstart精度評価は校正されたレンジファイ ンダを使って球体を計測し，その測定結果を用いて行われ た。図 7 はレンジファインダの正面に配置された五個の球 体（半径 $25 \mathrm{~mm}$ ) を示している。各球体には左上から右下 の順に番号（No.1〜No.5）が割り振られている。これらの 球体を計測し, 測定結果として得られる三次元座標に対し て球のあてはめを行い，その中心点を算出する。この中心 点と球体表面の計測点とのユークリッド距離を半径の実測 值と定める。半径の実測值 $r_{j}$ と理論值 $\hat{r}$ との誤差は
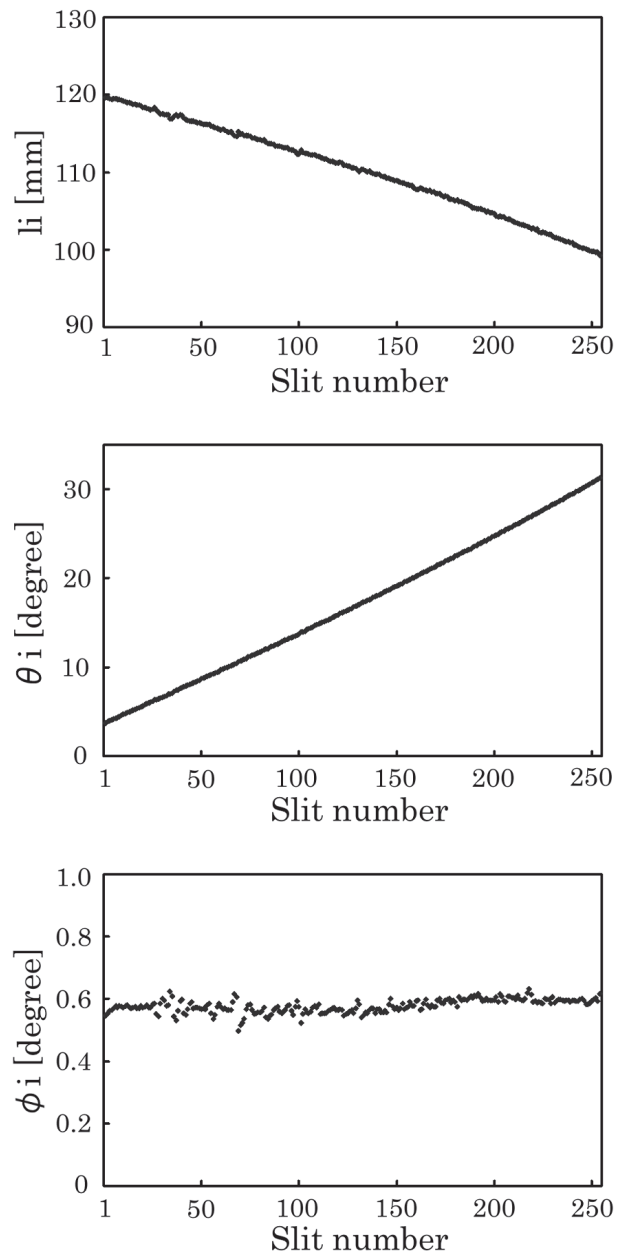

Fig. 6. Projector parameters.

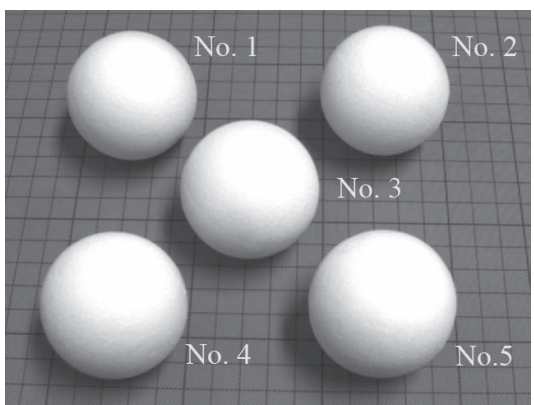

Fig. 7. Evaluation spheres.

$$
E=\frac{1}{N} \sum_{j=1}^{N}\left(r_{j}-\hat{r}\right)^{2} \ldots \ldots \ldots \ldots \ldots \ldots \ldots
$$

と定義する。 $N$ は球体の計測点数である。

提案法の有効性を示すために，以下の三手法で精度評価 を行った。

(i) スライドテーブルによるピンホールモデルの校正 : カメラとプロジェクタをそれぞれ $3 \times 4$ カメラ行列, $2 \times 4$ 投影行列によってモデル化し，スライドテーブルによって 校正する。二つの行列は同一平面上にない校正点から推定 する(12)。 
Table 2. Measurement error.

\begin{tabular}{|c|c|c|c|c|c|c|c|}
\hline & & & No. 1 & No. 2 & No. 3 & No. 4 & No. 5 \\
\hline & The number of points & & 15,629 & 15,629 & 19,405 & 19,861 & 19,861 \\
\hline (i) & Pinhole model & & & & & & \\
\hline & calibrated by slide table & {$\left[\mathrm{mm}^{2}\right]$} & 0.41 & 0.38 & 0.26 & 0.26 & 0.31 \\
\hline (ii) & $\begin{array}{l}\text { Equation of a plane model } \\
\text { calibrated by slide table }\end{array}$ & {$\left[\mathrm{mm}^{2}\right]$} & 0.22 & 0.31 & 0.19 & 0.13 & 0.20 \\
\hline (iii) & $\begin{array}{l}\text { Equation of a plane model } \\
\text { calibrated by reference plane }\end{array}$ & {$\left[\mathrm{mm}^{2}\right]$} & 0.23 & 0.32 & 0.21 & 0.15 & 0.21 \\
\hline
\end{tabular}

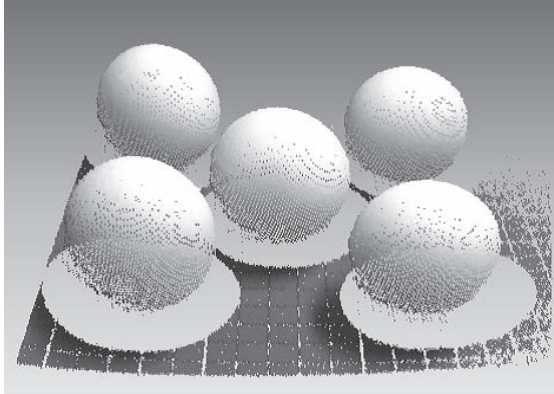

(i) Pinhole model calibrated by slide table

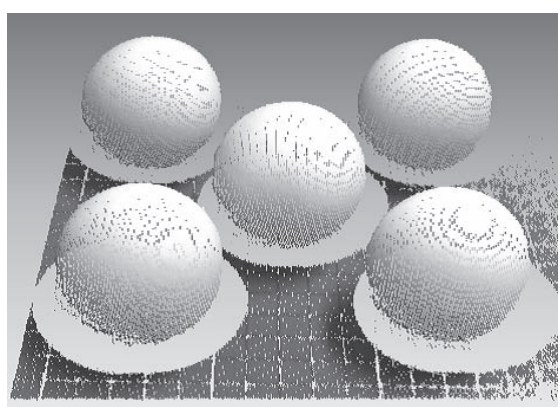

(ii) Equation of a plane model calibrated by slide table

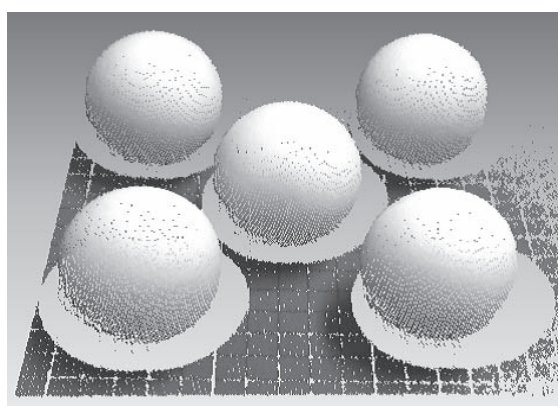

(iii) Equation of a plane model calibrated by reference plane

Fig. 8. Measurement result of spheres.

(ii） スライドテーブルによる平面方程式モデルの校正： カメラの幾何をピンホールモデル，プロジェクタから照射 されるスリット光を平面方程式によってモデル化し，スラ イドテーブルによって校正する。カメラパラメータは Tsai の手法 (13) から取得し，プロジェクタパラメータは提案法 より推定する。

（iii）基準平面を用いた平面方程式モデルの校正（提案 法）：カメラの幾何をピンホールモデル, プロジェクタ から照射されるスリット光を平面方程式によってモデル化
し，基準平面を用いて校正する。カメラパラメータ，プロ ジェクタパラメータはともに提案法によって推定する。

図 8 は球体の計測結果を点群表示したものである。手法 (i) の左側に位置する No.1 と No.4の球体が楕円形に歪んで計 測されており，球が配置された床面が湾曲していることが 分かる。対照的に, 手法 (ii), 提案法 (iii) にはそのような 歪みが見られなかった。

表 2 は五個の球体それぞれの計測誤差である。手法 (i)の 誤差は, 手法 (ii), 提案法 (iii) と比較してもっとも高い。こ れはプロジェクタにおいて，ピンホールモデルよりも，平 面方程式で定義したモデルの方が, 高精度な三次元計測を 行えることを示している。また，提案法 (iii) の誤差が手法 (ii) よりもわずかに高いのは，前者は基準平面を用いるた けであるのに対して, 後者は高精度なスライドテーブルを 利用しているためである。

したがって，これらの手法はスリット光を平面方程式に よってモデル化することが，ピンホールモデルを使うこと よりも精度が良いことを表しており，本論文で提案する平 面方程式によるモデルの優位性を示している。さらに，ス ライドステージを利用した場合と比べ, 同等の計測精度を 簡便な方法によって実現している提案法の有用性は高い。

\section{5. むすび}

基準平面を用いたスリット光投影式レンジファインダの 校正手法を提案した。本論では, カメラの幾何をピンホー ルモデル，プロジェクタから照射されるすべてのスリット 光を平面方程式で定義したモデルを用いた。カメラとプロ ジェクタのパラメータは基準平面を三視点から撮影するこ とによって校正できる。実験では，プロジェクタに対して ピンホールモデルを用いるよりも, 提案モデルを利用した ほうが高精度な測定結果が得られることを示した。さらに, 提案モデルをスライドテーブルと基準平面の二種類の方法 で校正した場合，計測精度に大きな違いが見られなかった。 そのため，基準平面を用いた本手法の有用性を示すことが できた。

(平成 21 年 1 月 4 日受付)

\section{文献}

(1) Y. Shirai and M. Suwa: "Recognition of polyhedrons with a range-finder", Proc. of 2nd Int. Joint Conf. Artificial Intell., pp.80-87 (1971) 
(2) J. L. Posdamer and M. D. Altschuler: "Surface measurement by space-encoded projected beam systems", Comput. Graph. Image. Processing, Vol.18, pp.1-17 (1982)

(3) B. Zhang, Y. F. Li, and Y. H. Wu: "Self-recalibration of a structured light system via plane-based homography", Pattern Recognition, Vol.40, No.4, pp.1368-1377 (2007)

（4）植芝俊夫·吉見 隆·大島正毅:「光学系の 3 次元モデルに基づくレン ジファインダの高精度キャリブレーション法」, 信学論, J74-D-II, 9, pp.1227-1235 (1991)

（5）服部数幸・佐藤幸男：「レーザパターンシフトによる高分解能空間 コード化法」, 信学論, J80-D-II, 6, pp.1423-1431 (1997)

（6）長谷川一英・野田一房・佐藤幸男：「3 次元計測機能を備えた電子内 視鏡装置」, 信学論, J84-D-II, 6, pp.1222-1230 (2001)

(7) O. Faugeras and Q. T. Luong: The Geometry of Multiple Images, MIT Press, Cambridge, Mass. (2001)

(8) G. Wei and S. Ma: "Implicit and explicit camera calibration: Theory and experiments", IEEE trans. Pattern Anal. Mach. Intell., Vol.16, No.5, pp.469-480 (1994)

(9) Z. Zhang: "A flexible new technique for camera calibration", IEEE trans. Pattern Anal. Mach. Intell., Vol.22, No.11, pp.1330-1334 (2000)

(10) Z. Zhang: "A flexible new technique for camera calibration", Technical Report MSR-TR-98-71, Microsoft Research (1998)

(11) SPACEVISION Incorporated: "Handy 3D Camera Cartesia", http://www.space-vision.jp/

（12） 井口征士・佐藤宏介：「三次元画像計測」，昭晃堂 (1990)

(13) R. Y. Tsai: "A versatile camera calibration technique for high-accuracy 3D machine vision metrology using off-theshelf TV cameras and Lens", IEEE J. Robot. Autom., Vol.3, No.4, pp.323-344 (1987)

山 内 航一郎

（非会員） 2004 年名工大·工·電気情報卒業。2006 年慶應義塾大学大学院 · 理工・修士課程修了。現 在同大学大学院後期博士課程に在学中。2007 年 グローバル COE プログラム研究員。2008 年カリ フォルニア大学リバーサイド校客員研究員。物体 の三次元計測, モデリング, 形状解析に関する研 究に従事。電子情報通信学会, 情報処理学会会員。

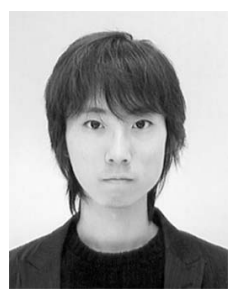

斎 藤 英 雄 （正員） 1987 年慶應義塾大学理工学部電気工学

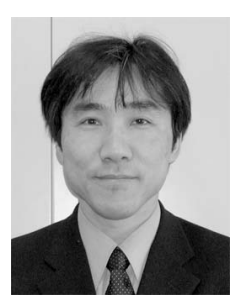
科卒業。1992 年同大学院理工学研究科博士課程 電気工学専攻修了。1992 年同大学助手。同講師, 同助教授を経て，2006 年同教授。1997～1999 年 米国カーネギーメロン大学ロボット工学研究所訪 問研究員。2000 2003 年科学技術振興事業団さ きがけ研究 21 「情報と知」領域研究員兼務。博士 (工学)。主としてコンピュータビジョンに関する 研究に従事。電子情報通信学会, 情報処理学会, 映像情報メディア学 会, 日本 VR 学会, IEEE 会員。

佐 藤 幸 男 （非会員） 1980 年慶應義塾大学大学院博士課程修

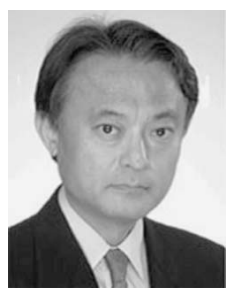
了。工学博士。同年東京農工大学助手。1983 年名 古屋工業大学講師, 助教授を経て 1995 年同大学 教授。1986 年カリフォルニア大学サンタバーバ ラ校客員準教授, 1987 年南カリフォルニア大学 客員研究員, 2001 年コロンビア大学客員研究員。 2005 年慶應義塾大学理工学部教授。コンピュータ ビジョンとパターン認識, 三次元物体の形状計測 等の研究に従事。IEEE, 情報処理学会, 計測自動制御学会等各会員。 